\title{
Computer Model Development on Contact-Stabilization Wastewater Treatment Systems
}

\author{
Priana Sudjono ${ }^{1)}$, Park Sang Sook ${ }^{2)}$ and A. Cahyo ${ }^{1)}$ \\ ${ }^{1)}$ Dept. of Environmental Engineering - ITB \\ Fax +62 022 2534166; Email: memteq@ bdg.centrin.net.id \\ ${ }^{2}$ Dept of Environmental Engineering \\ Sunchon University Korea
}

\begin{abstract}
Computer model is developed to relate parameters that determine the performance of a contact-stabilization system. Based on mass and substrate balance in the system, relationships between the variables are developed, then simulations using various values of the parameters can produce trend lines indicating the behavior of a system as well as the required conditions to reach an expected performance. When the operating conditions, such as recycled sludge and wasted sludge are changed, the model demonstrates alterations of the performance consistent to the developed mathematical relationships. Additionally, the computer model shows that the results could produce further explanation on phenomena of biological processes in contact-stabilization systems.
\end{abstract}

Keywords: computer model, contact-stabilization, recycled sludge, wasted sludge.

\section{Pembuatan Komputer Model pada Sistim Pengolahan Air Buangan Kontak- Stabilisasi}

Sari. Suatu komputer model dibuat untuk menghubungkan parameter yang menentukan kinerja suatu sistim kontak-stabilisasi. Berdasarkan atas keseimbangan masa dan keseimbangan substrat didalam sistim, dibuat hubungan antara variabel, kemudian simulasi mempergunakan berbagai harga parameter dapat menghasilkan garis kecenderungan yang menunjukkan perilaku suatu sistim demikian pula kondisi yang dibutuhkan untuk mencapai kinerja yang diharapkan. Bilamana kondisi operasi, seperti sirkulasi lumpur dan pembuangan lumpur, diubah, model menunjukkan perubahan kinerja konsisten terhadap persamaan matematik yang dikembangkan. Selanjutnya, model menunjukkan bahwa hasil hitungan dapat menjelaskan lebih jauh phenomena proses biologi di sistim kontak-stabilisasi.

Kata kunci: komputer model, kontak-stabilisasi, sirkulasi lumpur, lumpur terbuang. 


\section{Introduction}

Contact-stabilization system is a biological wastewater treatment modified from activated sludge. In this case the process is separated into two different tanks, absorption process takes place in contact tank and then oxidation, when absorptive organic are metabolically assimilated, in stabilization tank. Concerning several variables involved in determining the efficiency of the systems, a mathematical model is required to justify the performance of the system quantitatively.

Research on contact-stabilization system had been done in laboratory and in field plants. Laboratory experiments modified detention time and sludge age to understand the behavior of a scaled system in treating wastewater from a textile industry [1,2]. Moreover, Dewanti [3] added recycled sludge as a variable to specify performance of a scaled system in treating the same wastewater. They found different optimum results, so that to analyze the performance of a system, further exploitations on the variables are necessary. In the research, mathematical relationships to be implied in a computer model have been developed then, through simulations, operations of a fullscaled system can be imitated.

The model is developed based on steady state conditions and the wasted sludge is discharged from the stabilization tank. Then simulations apply detention time as a fix variable, while recycled sludge and the amount of wasted sludge are placed as independent variables. Other data are the same as those in the laboratory experiments, so that comparisons to the simulation results and analyses on trend lines will explain the behavior of the system.

\section{Method}

\subsection{Governing Equation}

The governing equations are based on an assumption that the system is under a steady state condition. Additionally, there is no microorganism's activity in clarifier, and growth-yield coefficients in both tanks are similar. Mathematical model is derived from a system as schematized in Figure 1. 


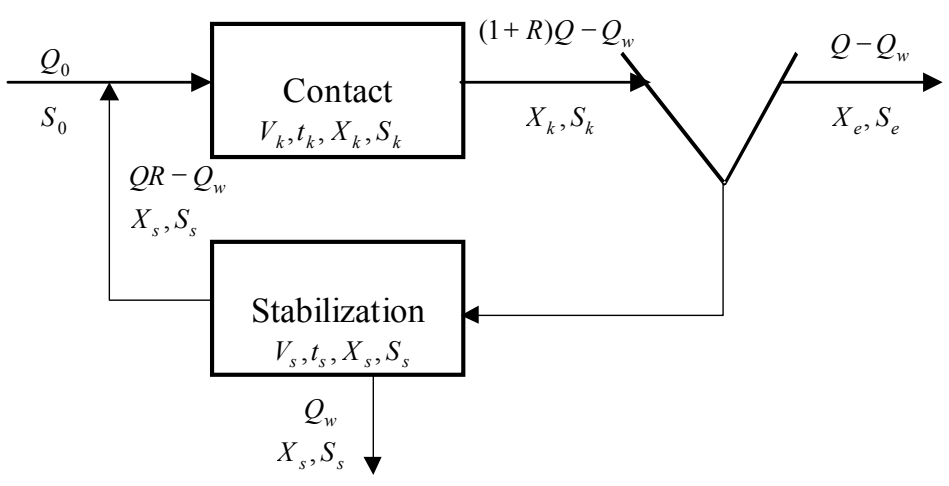

Figure 1 The diagram on contact-stabilization systems

The volume of the tanks:

$$
\begin{aligned}
& V_{k}=\left(Q+Q \cdot R-Q_{w}\right) \cdot t_{k} \\
& V_{s}=(Q \cdot R) \cdot t_{s}
\end{aligned}
$$

\subsubsection{Mass Balance}

The principle of mass balance, as described elsewhere, is applied in every unit in the system.

Rate of mass accumulated $=$ rate of mass in influent - rate of mass in effluent + rate of mass growth in the systems

Contact tank

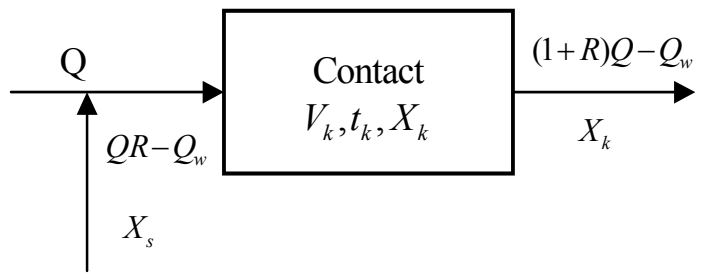

Figure 2 Mass balance in contact tank 
The equation on mass balance in contact tank is:

$\left(\frac{d X}{d t}\right)_{k} \cdot V_{k}=\left(Q \cdot R-Q_{w}\right) \cdot X_{s}-\left(Q \cdot R+Q-Q_{w}\right) \cdot X_{k}+V_{k} \cdot \mu_{k} \cdot X_{k}$

In steady state condition, $d X / d t=0$.

So that, the following function can be written as

$\frac{X_{k}}{X_{s}}=f\left(R, Q_{w}, t_{k}, \frac{1}{\left(1-\mu_{k}\right)}\right)$

Clarifier

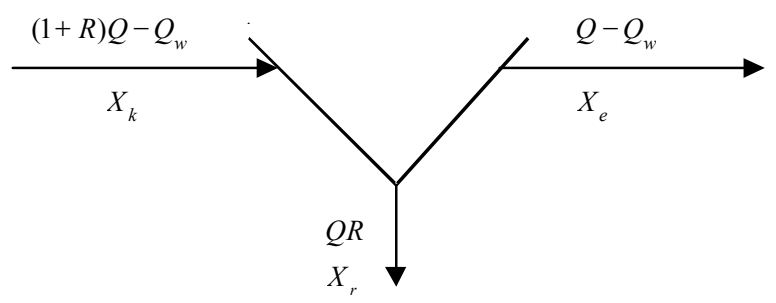

Figure 3 Mass balance in clarifier

The equation on mass balance in clarifier is:

$\left(Q \cdot R+Q-Q_{w}\right) \cdot X_{k}=Q \cdot R \cdot X_{r}+\left(Q-Q_{w}\right) \cdot X_{e}$

Assuming that the effluent does not content microorganisms: $X_{e}=0$

Then, it is found that

$X_{r}=f\left(Q, R, Q_{w}, X_{k}\right)$

Stabilization tank

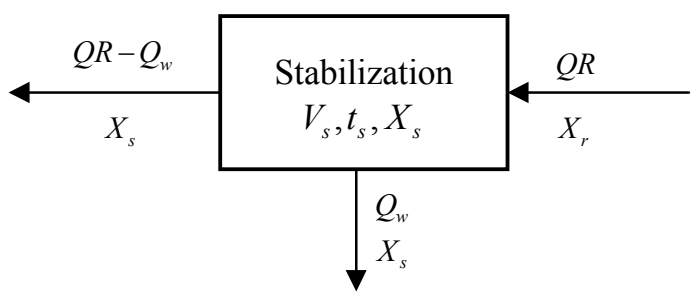

Figure 4 Mass balance in stabilization tank 
The equation on mass balance in stabilization tank is :

$\left(\frac{d X}{d t}\right)_{s} \cdot V_{s}=Q \cdot R \cdot X_{r}-\left(Q \cdot R-Q_{w}\right) X_{s}-\left(Q_{w} \cdot X_{s}\right)+V_{s .} \mu_{s} \cdot X_{s}$

Assuming that the system is operated in steady state conditions:

$d S / d t=0$; so that the composition of microorganisms in the system can be written in a function as

$\frac{X_{k}}{X_{s}}=f\left(R, Q_{w}, t_{s},\left(1-\mu_{s}\right)\right)$

Sludge age is the length of time that sludge stays in a system, so

$\theta_{C}=\frac{V_{k} \cdot X_{k}+V_{s} \cdot X_{s}}{Q_{w} \cdot X_{s}-Q_{i} \cdot X_{i}+Q_{e} \cdot X_{e}}$

Assuming that there is no microorganism in influent and effluent: $X_{i}=X_{e}=0$, and substituting equation (1), and (2) into (9), then

$\theta_{c}=f\left(\frac{X_{k}}{X}, Q, Q_{w}, R, t_{k}, t_{s}\right)$.

Rearranging function (10), the following relationships can be found

$\frac{X_{k}}{X_{s}}=f\left(\theta_{c}, t_{k}, t_{s}, Q, R, Q_{w}\right)$

$R=f\left(Q_{w}, Q, t_{k}, t_{s}, \theta_{c}, \frac{X_{k}}{X_{s}}\right)$

\subsubsection{Substrate balance}

The principle of substrate balance, as described elsewhere, is applied in every unit in the system.

Rate of substrate accumulation $=$ rate of influent substrate - rate of effluent substrate + rate of removal

Derivation of equations is based on substrate balance and adopts an assumption that Growth Yield coefficient of the microorganisms in both tanks is similar, or $Y=Y_{k}=Y_{s}$. 
Contact tank

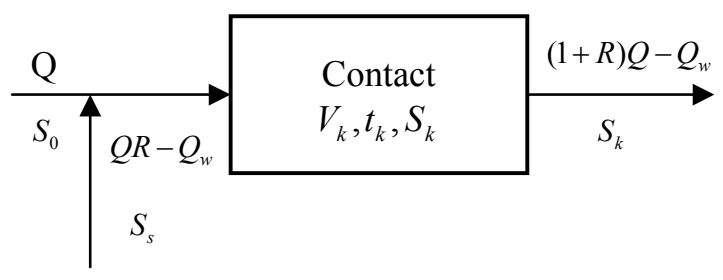

Figure 5 Substrate balance in contact tank

The substrate balance equation can be written as:

$\left(\frac{d S}{d t}\right)_{k \cdot V_{k}}=Q \cdot S_{o}+\left(Q \cdot R-Q_{w}\right) \cdot S_{s}-\left(Q \cdot R+Q-Q_{w}\right) \cdot S_{k}-\frac{V_{k} \cdot X k \cdot \mu k}{Y}$

Assuming that the system is operated in steady state condition:

$d S / d t=0$, so that,

$\left(Q+Q \cdot R-Q_{w}\right) \cdot S_{k}=Q \cdot S_{o}+\left(Q \cdot R-Q_{w}\right) \cdot S_{s}-\frac{V_{k} \cdot X_{k} \cdot \mu k}{Y}$

Equation (14) will be able to calculate $S_{k}$ where the function will be:

$S_{k}=f\left(Q, S_{0}, S_{s}, R, Q_{w}, V_{k}, X_{k}, Y, \mu_{k}, t_{k}\right)$

Clarifier

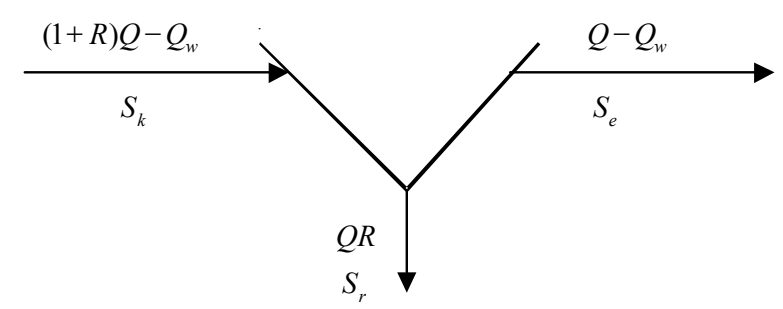

Figure 6 Substrate balance in clarifier

The substrate balance equation can be written as:

$\left(Q . R+Q-Q_{w}\right) \cdot S_{k}=\left(Q-Q_{w}\right) \cdot S_{e}+\left(Q . R . S_{r}\right)$

So, it is clear that 
$S_{r}=f\left(Q, R, Q_{w}, S_{e}, S_{k}\right)$

and,

$S_{e}=f\left(Q, R, Q_{w}, S_{r}, S_{k}\right)$

In case there is no microorganism's activity in clarifier, the above functions should adopt $S_{k}=S_{r}=S_{e}$

Stabilization tank

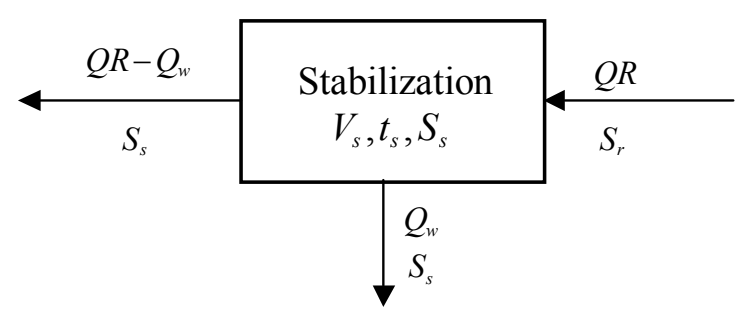

Figure 7 Substrate balance in stabilization tank

The substrate balance equation can be written as:

$\left(\frac{d S}{d t}\right) s . V_{s}=Q . R \cdot S_{r}-\left(Q . R-Q_{w}\right) \cdot S_{s}-Q_{w} \cdot S_{s}-\frac{V_{s . X s} \cdot \mu_{s}}{Y}$

Assuming that the system is operated in steady state conditions:

$d S / d t=0$; so that,

$\left(Q . R-Q_{w}\right) \cdot S_{s}+Q_{w} \cdot S_{s}=Q \cdot R \cdot S_{r}-\frac{V_{s \cdot} X_{s .} \mu_{s}}{Y}$

Rearranging equation (20) substrate in stabilization tank can be defined as: $S_{s}=f\left(S_{k}, X_{s}, \mu_{s}, Y, t_{s}\right)$

Rearranging equation (21) by substituting equation (2), the following function can be written:

$S_{k}=f\left(Q, S_{0}, R, Q_{w}, X_{k}, X_{s}, \mu_{s}, \mu_{k}, Y, t_{s}, t_{k}\right)$

\section{Efficiency}

Based on substrate balance, a mathematical model on efficiency of the systems can be developed. The model relates substrate removal, hydraulic detention time in contact tank and stabilization tank, sludge recycle, and sludge age. 


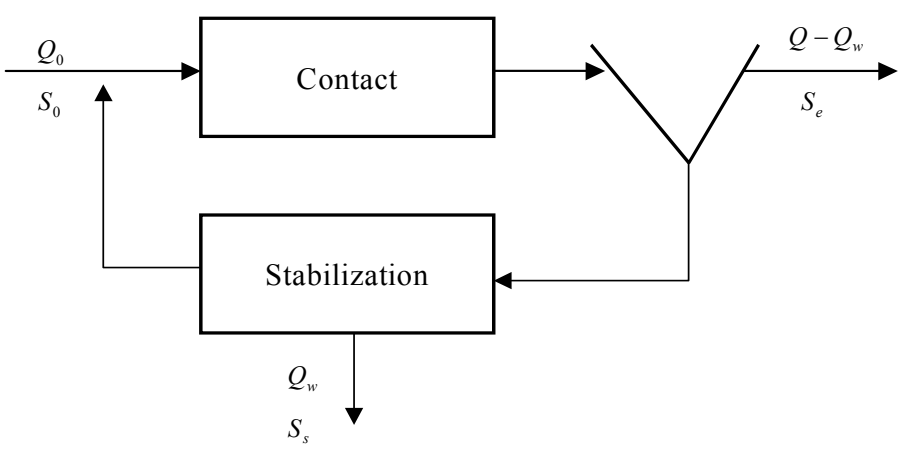

Figure 8 Contact-stabilization system for efficiency model

A principle applied in computing efficiency of the system:

rate of substrate weight in the influent = rate of substrate weight in the effluent

Incoming mass into the systems:

$Q . S_{o}=\left(Q-Q_{w}\right) \cdot S_{e}+Q_{w} \cdot S_{s}+\frac{\mu k \cdot X_{k} \cdot V_{k}}{Y}+\frac{\mu s \cdot X_{s} \cdot V_{s}}{Y}$

The mass in the effluent:

$Q .\left(S_{o}-S_{e}\right)=Q_{w} \cdot\left(S_{s}-S_{e}\right)+\frac{\mu k \cdot X_{k} \cdot V_{k}+\mu_{s} . X_{s} . V_{s}}{Y}$

The efficiency: $\eta=\frac{S_{0}-S_{e}}{S_{0}}$

Substituting equation (23) and (24) into (25), it is found that

$S_{0}-S_{e}=f\left(Q, Q_{w}, R, X_{k}, X_{s}, \mu_{k}, \mu_{s}, X_{k}, X_{s}, t_{k}, t_{s}, Y\right)$

However, the equation of efficiency is not simple but many variables involve in the equation. The most crucial variable should be known is the amount of microorganism in the tanks. So that, the function on efficiency is rewritten as the following relations: 
$\frac{\eta}{X_{k}}=f\left(S_{0}, Q, \theta_{c}, t_{s}, t_{k}, \mu_{k}, \mu_{s}, R, Q_{w}, Y\right)$
$\frac{\eta}{X_{s}}=f\left(S_{0}, Q, \theta_{c}, t_{s}, \mu_{k}, \mu_{s}, R, Q_{w}, Y\right)$

Using substrate balance relationships, the efficiency of the system can be written as; $\eta=f\left(S_{0}, Q, X_{k}, X_{s}, \theta_{c}, t_{k}, t_{s}, \mu_{k}, \mu_{s}, R, Q_{w}, Y\right)$

Note:

$Q, Q_{e}, Q_{w} \quad$ : flow of influent, effluent, and wasted sludge

$R \quad:$ sludge recycle ratio

$V_{k}, V_{s} \quad$ : volume of contact tank and stabilization tank

$S_{0}, S_{k}, S_{s}, S_{e}$ : substrate concentration in influent, contact tank, stabilization tank and effluent

$X_{k}, X_{s}, X_{r}, X_{e}$ : concentration of microorganism in contact tank, stabilization tank, recycled sludge, and effluent

$t_{k}, t_{s} \quad:$ detention time in contact tank, and stabilization tank.

$\mu_{k}, \mu_{s} \quad$ : specific growth rate of microorganism in contact and stabilization tank

$Y \quad$ : growth yield coefficient

$\theta_{c} \quad$ : sludge age

$\eta \quad$ : overall efficiency of a system

\subsection{Formulae Transformation}

The formulae on contact stabilization-systems are transformed into a computer model using FORTRAN. The model is designed for simulation based on values of detention time and specific growth rate. Flowchart of the computer program is shown in Figure 9. 


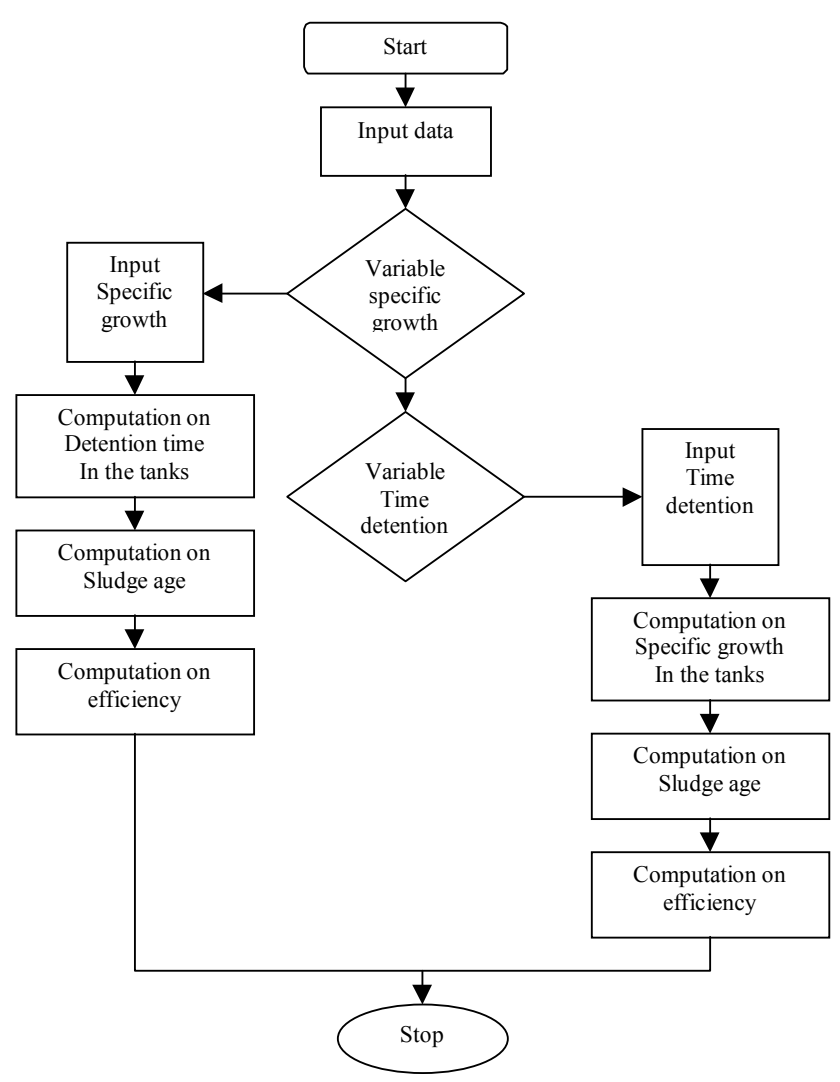

Figure 9 The flowchart of the computer model on Contact-Stabilization System

\subsection{Simulation}

Simulation using the computer model is conducted using physical data of a reactor that is used in laboratory experiment. The results can be compare to find the reasons on similarities and differences when several values of detention time or wasted sludge are adopted. These mean that the results from laboratory experiments will be approached by several reactor dimensions and several types of operations. Tables showing relationships between variables such as $X_{k} / X_{s}, \mu_{k}, \mu_{s}, \theta_{c}$, and $\eta$ can lead to understanding on behavior of wasted sludge and recycled sludge. 


\section{Results and Discussion}

The developed computer model is run to find several possible values of operating parameters, ie. rate of recycled sludge and wasted sludge. The values, then, are compared to results from laboratory experiments in order to indicate performance of the model. Conversely, the comparison of both may also indicate problems in scaled system commonly used in laboratories.

In case wasted sludge is $0,01 \mathrm{~L} /$ hour, and the detention time in contact tank 1 hour and in stabilization tank 3 hour, relationship between $X_{k} / X_{s}$ and $\mu_{k}, \mu_{s}$ are shown in Figure 10 and 11. The figures indicate that $X_{k} / X_{s}$ rises as recycled sludge increases. Figure 10 shows that increment of $\mu_{k}$ raises $X_{k} / X_{s}$ as in formula (4) that is $\frac{X_{k}}{X_{s}}=f\left(R, \frac{1}{\left(1-\mu_{k}\right)}\right)$. While Figure 11 shows that increment of $\mu_{s}$ causes $X_{k} / X_{s}$ to decrease as it agrees with formula (8) that is $\frac{X_{k}}{X_{s}}=f\left(R,\left(1-\mu_{s}\right)\right)$. However, both figures are very impractical to be used for evaluating performance of a system as specific growth rate plays major roles for the whole computations while its value is uneasy to be determined by laboratory experiments.

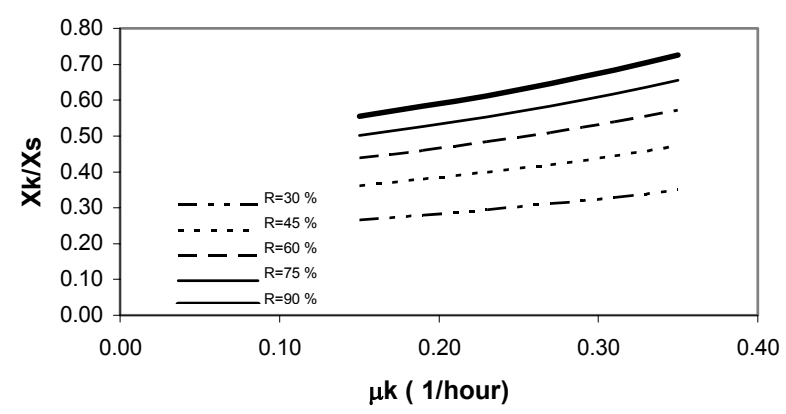

Figure 10 Relationships between specific growth $\left(\mu_{k}\right)$ and $X_{k} / X_{s}$ at wasted sludge $0.01 \mathrm{~L} /$ hour, detention time in contact tank 1 hour and in stabilization tank 3 hour 


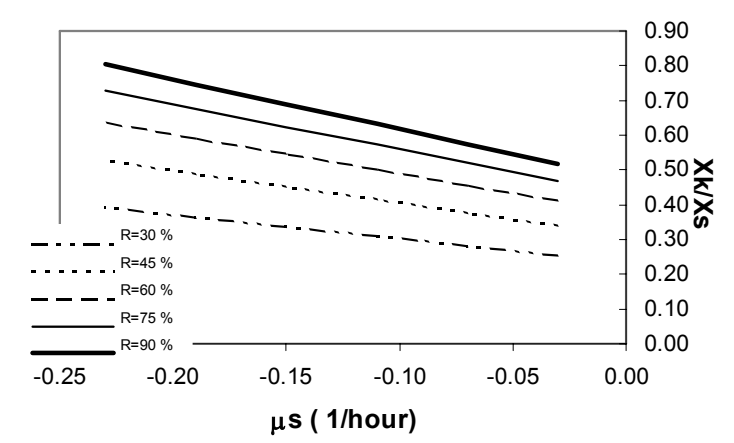

Figure 11 Relationships between specific growth $\left(\mu_{s}\right)$ and $X_{k} / X_{s}$ at wasted sludge $0.01 \mathrm{~L} /$ hour, detention time in contact tank 1 hour and in stabilization tank 3 hour

The value of $X_{k} / X_{s}$ is used to estimate sludge-age $\left(\theta_{c}\right)$ for a given rate of recycled sludge $(R)$ as in Figure 12. For a value of $X_{k} / X_{s}$ the sludge-age enlarges as rate of recycled sludge increases. Further consequence is that the volumes of the tank increase for a value of detention time as indicated by equation (1) and (2). Additionally, equation (9) defines that the sludge-age increases as the volumes of the tank rise. It means that Figure 12 is a characteristic of contact-stabilization systems for a single value of detention time and wasted sludge. Cho et al [4] mentioned that recycled sludge and wasted sludge as operating parameters can control biomass concentrations and efficiency besides considered coupling function of aeration tank and secondary settling tank. Other computations using several values of wasted sludge are also necessary to analyze the characteristics of a system based on the developed formulae. 


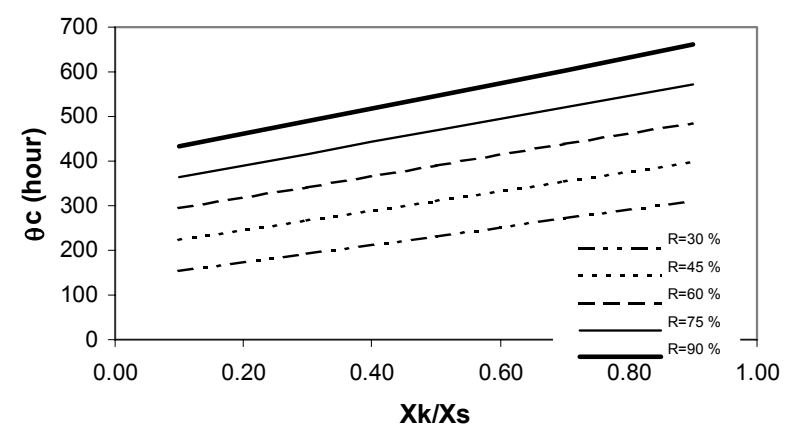

Figure 12 Relationships between sludge age $\left(\theta_{c}\right)$ and $X_{k} / X_{s}$ at wasted sludge $0.01 \mathrm{~L} /$ hour, detention time in contact tank 1 hour and in stabilization tank 3 hour

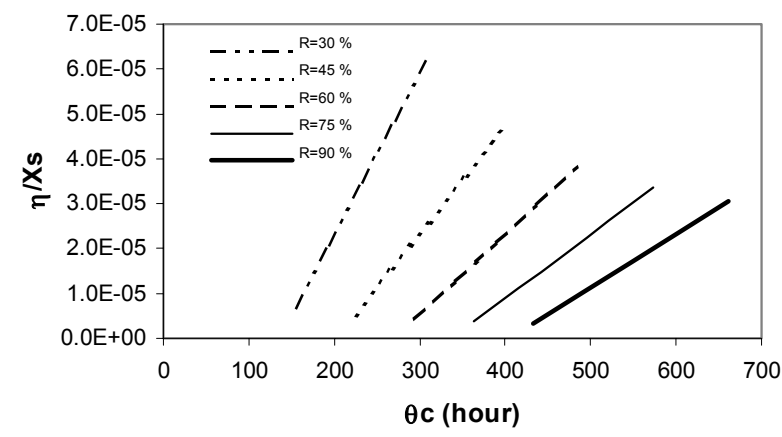

Figure 13 Relationships between sludge age $\left(\theta_{c}\right)$ and efficiency as $\frac{\eta}{X_{s}}$ at wasted sludge $0.01 \mathrm{~L} /$ hour, detention time in contact tank 1 hour and in stabilization tank 3 hour

Figure 13 shows relationships between sludge-age $\left(\theta_{c}\right)$ and efficiency per biomass as $\frac{\eta}{X_{s}}$. Given a sludge-age and a rate of recycled sludge, the figure appoints to a value of efficiency. It clearly shows that efficiency depends on 
accurate estimation on biomass in the tanks. Otherwise, estimated efficiency will be different from the expected one. Because small number of $\frac{\eta}{X_{s}}$ is sensitive to the number of biomass that is quite large comparing to the number of efficiency. By controlling the amount of biomass in aeration tank through adjustment on wasted sludge, performance of a system can be managed [5]. At least, the figure leads to a conclusion that efficiency of a system rises as the sludge-age increases. Further analyses on the simulation results are conducted through making comparison of those to the results from a laboratory experiment using a small-scaled system. It treats wastewater from palm oil refinery [6] that the concentrations are around ten thousands $\mathrm{mg} / \mathrm{L}$ COD. The simulation results and the laboratory experiment are presented in Table 1.

\begin{tabular}{|c|c|c|c|c|c|c|c|c|c|c|}
\hline Parameter & $\begin{array}{c}\text { Lab. } \\
\text { Experi } \\
\text { Ment") }\end{array}$ & \multicolumn{9}{|c|}{ Simulation } \\
\hline $\begin{array}{c}\text { Recycled } \\
\text { sludge } \\
(\%)\end{array}$ & 75 & \multicolumn{3}{|c|}{60} & \multicolumn{3}{|c|}{75} & \multicolumn{3}{|c|}{90} \\
\hline $\begin{array}{c}\text { Micro. in } \\
\text { Stabilizatio } \\
\mathrm{n} \text { tank } \\
(\mathrm{mg} / \mathrm{l})\end{array}$ & 16425 & 16425 & 20889 & 16425 & 16425 & 33571 & 16425 & 16425 & 64828 & 16425 \\
\hline $\begin{array}{c}\text { Sludge-age } \\
\text { (hour) }\end{array}$ & 380 & 520 & 520 & 580 & 520 & 520 & 710 & 520 & 520 & large \\
\hline $\begin{array}{c}\text { Efficiency } \\
(\%)\end{array}$ & 94 & 76 & 94 & 94 & 46 & 94 & 94 & 24 & 94 & 94 \\
\hline
\end{tabular}

Source: ${ }^{*}[6]$

Table 1 Simulation result for wasted sludge 0,01 L/hour comparing to laboratory experiment

Results from laboratory experiments using scaled-system in treating wastewater is compared to computer simulation results. The experiment specifies that sludge-age is 380 hours based on assumption that volumes of the tanks are computed by only taking account on the flow of wastewater to 
be treated. Otherwise, based on formulae (9), sludge-age is 520 hours for 0.01 L/hour wasted sludge.

If efficiency and sludge-age should be the same as those in the experiment, the simulation results show higher biomass in the stabilization tank. Otherwise, longer sludge-age is necessary to reach the same efficiency by the same amount of biomass. Simulation results by employing recycled sludge 60 percent are fairly close to the results of the experiment. Because the consequence of ignoring recycled sludge in computing tank's dimension decreases of the actual value of recycled sludge as it can be found from equation (2). Mystery behind the different amount of required biomass in the tank could lead to several speculations. Those differences might be caused by high substrate concentration used in the laboratory experiment and small number of samples taken during the experiment. It has also been warned that alteration on sludge age, as variable in the experiment, may influence the existence of microorganisms [7]. Thus careful experiments are required, as steady state conditions should be achieved before samples are taken. Some differences on values of microorganism growth rate and the yield coefficient were also found in validating a model using parameter from bibliography which remain constant with time and values for parameters which vary with time [8]. In fact, the amount of biomass in a small-scaled system is very sensitive to fluctuate as this is under the influence of recycled sludge and rate of wasted sludge. However, the computer model shows that the results could produce further explanation on phenomena of biological processes in contact-stabilization systems.

\section{$4 \quad$ Conclusion}

A contact-stabilization system is a complicated biological treatment involving several parameters that should be adjusted to reach an optimum efficiency. Based on mass and substrate balance in the tanks, formulae relating parameters are developed. Then the formulae are transformed into a computer model for simulations. In case detention time is a fixed variable, recycled sludge and wasted sludge are parameters to determine the amount of biomass in the tanks, sludge-age, and efficiency of the treatment systems. 
Further analyses by comparing simulation results with laboratory experiment found that the amount of biomass should be measured accurately at every adopted value of recycled sludge and wasted sludge during the experiment. When the operating conditions, such as recycled sludge and wasted sludge are changed, the model demonstrates alterations of the performance consistent to the developed mathematical relationships. Further, the computer model shows that the results could produce further explanation on phenomena of biological processes in contact-stabilization systems.

\section{References}

1. Rosfida, S.H. Pengaruh Umur Lumpur dan Waktu Detensi Hidrolis dalam Proses Kontak Stabilisasi yang Dikombinasikan dengan Adsorbsi Karbon Aktive dalam Pengolahan Air Buangan Industri Tekstil. Bachelor of Engineering thesis in the Dept. of Environmental Engineering of the Bandung Institute of Technology. 1994.

2. Fenita. Degradasi Warna Kloroanilin dengan Menggunakan Reaktor Gabungan Aerob dan Kontak Stabilisasi. Bachelor of Engineering thesis in the Dept. of Environmental Engineering of the Bandung Institute of Technology. 2000.

3. Dewanti, O. Pengaruh Resirkulasi Lumpur pada Proses Kontak Stabilisasi dengan Kombinasi Karbon Aktive Granular untuk Pengolahan Air Buangan Industri Tekstil. Bachelor of Engineering thesis in the Dept. of Environmental Engineering of the Bandung Institute of Technology. 1995.

4. Cho, S.H., Chang, H.N., and C. Prost. Steady State Analysis of the Coupling Aerator and Sedimentary Settling Tank in Activated Sludge Process. Water Research, 30 (11):2601-2608 (1996).

5. Cakici, A., and M. Bayramoglu. An Approach to ControllingSludge Age in the Activated Sludge Process. Water Research, 29 (4):10931098 (1995).

6. Sesca Driandhini. Optimasi Umur Lumpur dan Resirkulasi Lumpur pada Proses Kontak Stabilisasi Untuk Penyempurnaan Kualitas 
Efluen Pengolahan Air Buangan Industri Minyak Kelapa Sawit. Bandung: Institut Teknologi Bandung. 1994.

7. Fujita, Masanori., Ike, Michihiko., and Kazuya Uesugi. Operation Parameters Affecting the Survival of Genetically Engineered Microorganisms in Activated Sludge Process. Water Research, 28 (7):1667-1672 (1994).

8. Garcia-Olivares, A., and E. Becares. Calibration of a Model for an A+B Activated Sludge Pilot Plant Treating Industrial Wastewater. Water Research, 29 (12):2673-2680 (1995). 